\title{
ОПТИМІЗАЦІЯ ТАКТИКИ ВЕДЕННЯ ЖІНОК ІЗ СИНДРОМОМ ВТРАТИ ПЛОДА НА ТЛІ ЕНДОТЕЛІАЛЬНОЇ ДИСФУНКЦІї
}

\begin{abstract}
Оптимізація тактики ведення жінок із синдромом втрати плода на тлі ендотеліальної дисфункції
\end{abstract}

Л. М. Маланчук, В. М. Мартинюк, С. Л. Маланчук

Тернопільський національний медичний університет імені І. Я. Горбачевського МОЗ України

Резюме. Зниження перинатальної захворюваності $\epsilon$ особливо важливим в аспекті покращення демографрічних показників в Україні. У сучасному акушерстві особлива увага приділяється питанням планування та підготовки до вагітності у жінок із синдромом втрати плода, частота якого є досить високою і коливається від 10 до $25 \%$.

Мета дослідження - розробити алгоритм лікувально-проорілактичних заходів для жінок із синдромом втрати плода на тлі ендотеліальної диссрункції шляхом патогенетично обгрунтованої корекції змін, виявлених під час вагітності.

Матеріали і методи. Для досягнення поставленої мети ми обстежили 150 вагітних, яких поділили на 3 групи по 50 жінок у кожній. Окрім обов'язкового обстеження вагітних, додатково проводилося визначення співвідношення альбумін/креатинін у сечі за допомогою тест-смужок Microalbuphan. Визначення концентрації оксиду азоту в крові виконувалося колориметричним методом. Дослідження фролієвої кислоти визначали за допомогою імунофрерментного аналізу, а концентрацію креатиніну в навколоплідних водах - на повіреному фотометрі МБА-540. Для подальшого гістологічного та мікроморфометричного дослідження провізорних органів плода, відбір матеріалу здійснювали після завершення третього періоду пологів.

Результати. Встановлено, що у пацієнток із синдромом втрати плода діагностується доклінічна гестаційна ендотеліальна дисфрункція, зниження вмісту фролієвої кислоти в крові, високі показники креатиніну в навколоплідних водах. При морфрологічному дослідженні провізорних органів плода відзначаються дистрофрічно-дегенеративні зміни із ознаками інфрікування. Після призначення вагітним донатору оксиду азоту L-аргініну аспартату та фролієвої кислоти ендотеліальна дисфуннкція не діагностувалась та нормалізувався вміст креатиніну в навколоплідних водах. При морфологічному дослідженні посліду спостерігались компенсаторно-пристосувальні зміни.

Висновки. Запропонована нами комплексна терапія із застосуванням донатору оксиду азоту та фролієвої кислоти значно покращила перинатальні наслідки у жінок із синдромом втрати плода. Так, у другій групі спостереження частота загрози переривання вагітності знизилась втричі, в шість разів - дистрес плода, вдвічі -
Management optimization of women with fetal loss syndrome associated with endothelial dysfunction L. M. Malanchuk, V. M. Martyniuk, S. L. Malanchuk I. Horbachevsky Ternopil National Medical University e-mail: martynjuk.victoriya@gmail.com

Summary. Reducing perinatal morbidity is especially important in terms of improving demographics in Ukraine. In modern obstetrics, special attention is paid to the planning and preparation for pregnancy in women with fetal loss syndrome, the frequency of which is quite high and ranges from $10 \%$ to $25 \%$.

The aim of the study - to develop an algorithm for treatment and prevention activities for women with fetal loss syndrome and endothelial dysfunction by pathogenically justified correction of changes detected during pregnancy.

Materials and Methods. To achieve our purpose, we examined 150 pregnant women, divided into 3 groups, of 50 women in each. In addition to the mandatory examination of pregnant women, the urinary albumin/ creatinine ratio was additionally determined using Microalbuphan test strips. Determination of the concentration of nitric oxide in the blood was performed by colorimetric method. Studies of folic acid were determined by enzyme-linked immunosorbent assay, and the concentration of creatinine in amniotic fluid - on a certified photometer MBA-540. For further histological and micromorphometric examination of the provisional organs of the fetus, the selection of material carried out after the third period of labor.

Results. So, patients with fetal loss syndrome are diagnosed with preclinical gestational endothelial dysfunction, decreased folic acid content in the blood, high levels of creatinine in amniotic fluid. At morphological research of provisional organs of a fetus dystrophic and degenerative changes with signs of infection are noted. After prescribing L-arginine aspartate and folic acid to a donor of nitric oxide, endothelial dysfunction was not diagnosed and creatinine content in amniotic fluid was normalized. Compensatory-adaptive changes were observed during morphological examination of placenta.

Conclusions. Our proposed complex therapy, using a donor of nitric oxide and folic acid, significantly improved perinatal outcomes in women with fetal loss syndrome. Thus, in group 2 of observations the frequency of threatened abortion decreased three times, six times - 
ургентних кесаревих розтинів порівняно з першою групою.

Ключові слова: синдром втрати плода; ендотеліальна дисорункція; перинатальні наслідки.

\section{ВСТУП}

Проблема невиношування вагітності є медикосоціальною проблемою, яка не тільки вказує на порушення репродуктивного здоров'я жінки, а також $€$ показником якості надання медичної допомоги. Рішення даної проблеми є одним із пріоритетів сучасного акушерства. Щорічно в світі народжується близько 15 млн недоношених дітей, а частота перинатальних ускладнень серед таких немовлят у 13-30 разів перевищує цей показник для дітей, народжених у термін. Приблизно 50 \% недоношених новонароджених залишаються глибокими інвалідами, що призводить до погіршення демограсрічної ситуації в державі та психосоматичного стану подружжя $[1,2]$. Частота самовільного переривання вагітності у популяції становить від 2 до 55 \%, при цьому в першому триместрі цей показник сягає близько $80 \%$ репродуктивних втрат. Після одного викидня в анамнезі ризик втрати бажаної вагітності становить 13-26 \%, а після двох самовільних абортів - цей показник зростає до $45 \%$. У реалізації синдрому невиношування вагітності бере участь цілий ряд патогенетичних фракторів. До таких відноситься плацентарна диссрункція, інфекційний агент, істміко-цервікальна недостатність, імунологічні реакції, нейроендокринні порушення, екстрагенітальні захворювання, більшість 3 яких супроводжуються гестагенною недостатністю, беручи початок ще з етапу прегравідарної підготовки [3]. Сучасні вітчизняні та зарубіжні наукові праці присвячені ліквідації етіологічного фрактора репродуктивних втрат або лікуванню наслідків його несприятливого впливу. Але, на нашу думку, вивчення основ патогенезу срормування синдрому втрати плода та розробка лікувально-профрілактичних заходів щодо своєчасної корекції виявлених під час вагітності порушень, $є$ запорукою збереження жінкою бажаної вагітності та народження здорового малюка $[4,5]$.

Метою дослідження було розробити алгоритм лікувально-профрілактичних заходів для жінок із синдромом втрати плода на тлі ендотеліальної дисфрункції шляхом патогенетично обґрунтованої корекції змін, виявлених під час вагітності.

\section{МАТЕРІАЛИ I МЕТОДИ}

Під нашим спостереженням перебувало 150 вагітних, які склали три групи дослідження по 50 жінок у кожній. До першої групи увійшли пацієнтки із синдромом втрати плода, які отримували загаль- fetal distress, twice - urgent cesarean section in comparison with group I.

Key words: fetal loss syndrome; endothelial dysfunction; perinatal consequences.

ноприйняте лікування за клінічними показаннями. Другу групу склали жінки, яким додатково з 12 тижнів вагітності призначали сироп L-аргініну аспартату по 5 мл (1 г діючої речовини) 3 рази на добу протягом 14 днів та фролієву кислоту в дозі 400 мкг на добу з 20 до 30 тижнів вагітності. Третю (контрольну) групу складали жінки без репродуктивних втрат в анамнезі. Спостереження проводилось 3 12 тижнів вагітності, при пологах та ранньому післяпологовому періоді. Обстеження вагітних проводили згідно з чинним наказом МОЗ України № 417 від 15.07.2011 р.

Додатково визначали співвідношення, дослідження крові для визначення концентрації оксиду азоту та фролієвої кислоти, біохімічний аналіз навколоплідних вод та морфологічне дослідження провізорних органів новонародженого.

3 метою діагностики доклінічної ендотеліальної дисфрункції використовували обчислення співвідношення альбумін/креатинін у сечі та концентрацію активних метаболітів оксиду азоту в крові. Дану концентрацію здійснювали за допомогою тест-смужок Microalbuphan (корисна модель № u201201377 від 2012 р.). Дослідження концентрації активних метаболітів оксиду азоту в крові проводилось колориметричним методом із використанням гранульованого кадмію в якості відновника. Визначення рівня фолієвої кислоти в сироватці крові виконували методом імуносерментного аналізу на апараті BioChem FC-360, а концентрацію креатиніну в навколоплідних водах - на повіреному фотометрі МБА-540 за інтенсивністю забарвлення утвореного розчину жовто-червоного кольору (похідне 2,4,6-три-нітроциклогексадієну). Для подальшого гістологічного та мікроморфометричного дослідження провізорних органів плода, відбір матеріалу здійснювали після завершення третього періоду пологів. Отримані взірці занурювали у $10 \%$ розчин формаліну, а після гістологічної проводки препарат заливали у парасрін. Депарафріновані зрізи забарвлювали гематоксиліном і еозином, пікрофуукином за методом ван Гізон.

Статистичні обрахунки отриманих результатів проводили за допомогою програмного забезпечення Microsoft Excel 2010 та у програмі Statistica 10, використовували t-критерій Стьюдента при рівні значущості $p \leq 0,05$.

\section{РЕЗУЛЬТАТИ Й ОБГОВОРЕННЯ}

У жінок із синдромом втрати плода в першому триместрі вагітності спостерігалась доклінічна 
гестаційна ендотеліальна дисфрункція. Показник співвідношенняальбумін/креатинін у сечі в першій групі був значно вищим $((10,68 \pm 0,48)$ мг/ммоль), ніж у вагітних без обтяжливого акушерського анамнезу $((1,67 \pm 0,04)$ мг/ммоль). Різниця між першою та третьою групами була статистично достовірною $(p \leq 0,05)$. У жінок без репродуктивних втрат в анамнезі концентрація фолієвої кислоти на 20 та 30 тижнях вагітності була в межах лабораторної норми $((8,35 \pm 0,26)$ нг/мл) та $((7,59 \pm 0,27)$ нг/мл) відповідно. Середня концентрація даного мікроелемента в жінок першої дослідної групи в 20 тижнів вагітності становила $((2,39 \pm 0,05)$ нг/мл), а в 30 тижнів - $((2,03 \pm 0,06)$ нг/мл). Отримані дані були нижче референтних значень, окрім цього відмічалась тенденція до подальшого зниження концентрації фролієвої кислоти в сироватці крові.

У жінок із синдромом втрати плода першої групи відзначалася значно вища концентрація креатиніну в навколоплідних водах - $((213,19 \pm 6,62)$ мкмоль/л) порівняно 3 роділлями без репродук-

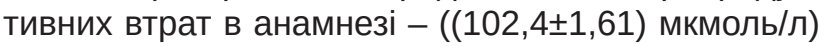
$(p \leq 0,05)$. У жінок із обтяженим акушерським анамнезом переважав магістральний тип васкуляризації та атипова фрорма палацент, спостерігалися виражені патологічні зміни з боку провізорних органів плода у вигляді набряку, варикозного розширення та справжніх вузлів судин пуповини, ділянок ішемії плаценти, червоних та білих інфрарктів, петрисрікатів, кіст плаценти, потовщення плодових оболонок. Також відмічалися дистрофрічно-дегенеративні процеси з розладом кровообігу та явищами інфікування.

У більшості жінок контрольної групи (78 \%) вагітність, пологи та післяпологовий період перебігали без ускладнень. Вроджених аномалій, деформацій та хромосомних порушень, а також окремих станів перинатального періоду в новонароджених не було зафріксовано.

Щодо жінок першої дослідної групи, то перебіг вагітності харатеризувався різноманітними ускладненнями. У 19 (38 \%) пацієнток була загроза викидня, в 6 (12 \%) - передчасних пологів, дистрес плода спостерігався у 6 (12 \%) вагітних, затримка

\section{СПИСОК ЛІТЕРАТУРИ}

1. Центр медичної статистики МОЗ України [Електронний ресурс]: [Веб-сайт].- Електронні дані. - Режим доступу: http://medstat.gov.ua/

2. Моісеєнко Р. О. Актуальні питання материнства і дитинства в Україні / Р. О. Моісеєнко // Здоровье женщины. - 2008. - № 4 (36). - С. 64-70.

3. Пирогова В. І. Синдром втрати плода: від науки до практики / В. І. Пирогова, С. О. Шурпяк // Здоров'я України. - 2014. - № 1. - С. 16-17. росту плода - в 5 (10 \%). Лише у 18 (36 \%) жінок цієї групи вагітність перебігала фрізіологічно.

Пологи супроводжувалися зростанням кількості ускладнень порівняно з групою контролю: у 3 (6 \%) породіль відбулися передчасні пологи, ургентний кесарів розтин виконаний у 8 (16 \%) жінок, первинна та вторинна слабкість пологової діяльності відмічалась у 8 (16 \%) випадків, стрімкі пологи відбулись у 3 (6 \%) пацієнток.

Вагітність у жінок із репродуктивними втратами в анамнезі другої групи перебігала з меншою кількістю ускладнень поріняно 3 першою: у 32 (64%) пацієнток вагітність перебігала фрізіологічно, втричі знизилась частота загрози переривання вагітності, анемії та гестозів, у шість разів - показник дистресу плода. У 29 (58 \%) випадків спостерігався фрізіологічний перебіг пологів, лише в 1 (2\%) особи відбулися передчасні пологи, ургентний кесарів розтин був виконаний у 4 (8 \%) породіль.

Таким чином, запропонована нами комплексна терапія із застосуванням донатору оксиду азоту та фолієвої кислоти значно покращила перинатальні наслідки у жінок із синдромом втрати плода. Науковцям необхідно продовжувати вивчати основи патогенезу формування синдрому втрати плода 3 метою зниження перинатальних ускладнень, адже формування здорової нації можливе лише за умови профрілактики захворюваності з моменту планування та виношування вагітності.

\section{ВИСНОВКИ}

1. Вагітним із синдромом втрати плода в 12 тижнів гестації необхідно визначати співвідношення альбумін/креатинін у сечі з метою ранньої діагностики ендотеліальної дисфункції.

2. При виявленні ранньої ендотеліальної дисфрункції вагітним із синдромом втрати плода рекомендовано призначати донатор оксиду азоту - сироп L-аргініну аспартату по 5 мл 3 рази на день 3 12 тижнів гестації.

3. На 20 тижні вагітності у жінок із синдромом втрати плода необхідно визначити рівень фолієвої кислоти в крові. Низька концентрація мікроелемента $є$ показанням до призначення вагітним фролієвої кислоти в дозі 400 мкг на добу протягом 10 тижнів.

4. Маланчук Л. М. Синдром втрати плода: сучасні підходи до лікування / Л. М. Маланчук, 3. М. Кучма, С. Л. Маланчук // Медицинские аспекты здоровья женщины. - 2015. - № 9 (95). - С. 19-22.

5. American College of Obstetricians and Gynaecologists. "Practice Bulletin/Management of preterm labor" // Obstet. Gynecol. - 2012. - Vol. 119. - P. 13081313.
Вісник медичних і біологічних досліджень Bulletin of Medical and Biological Research 


\section{REFERENCES}

1. Center for Medical Statistics of the Ministry of Health of Ukraine. Available from: http://medstat.gov.ua/ [in Ukrainian].

2. Moisenko PO. [The topical issues of motherhood and childhood]. Zdorovia zhenshchiny. 2008;4(36): 64-70 [in Ukrainian]

3. Pyrohova VI, Shurpyak SO. [Fetal loss syndrome: from science to practice]. Zdorovia Ukrainy. 2014;1: 16-7 [in Ukrainian]
4. Malanchuk LM, Kuchma ZM, Malanchuk SL. [Fetal loss syndrome: modern approaches to treatment]. Meditsinskiye aspekty zdorovya zhenshchiny. 2015;9(95): 19-22 [in Ukrainian].

5. American College of Obstetricians and Gynaecologists. "Practice Bulletin. Management of preterm labor". 2012;119: 1308-13.

Отримано 06.08.20 